\title{
A mutation breeding programme for sprouting resistance in bread wheat
}

\author{
E. I. Krvi and S. Hovinen \\ Hankkija Plant Breeding Institute, SF-04300 Hyrylä, Finland
}

\begin{abstract}
A breeding programme involving ${ }^{60} \mathrm{Co}$ mutagen treatment of the early maturing, hexaploid spring wheat variety Ruso, is described. The initial objective of the breeding work was to improve Ruso's resistance to sprouting in the ear. Treatment in the moist chamber followed by falling number tests were used for screening the mutants. Several very sprouting resistant but late maturing mutants were found. None the less efforts were made to retain also the earliness of the mother variety in the sprouting resistant mutants. In the $\mathrm{M}_{10}$ generation, there remained four usable early mutant lines showing a clear improvement in sprouting resistance. Two of them, in addition, have remarkably stiff straw, even when compared with the already very lodging resistant mother variety.
\end{abstract}

In 1967, the Hankkija Plant Breeding Institute released a new spring wheat variety, Ruso. Within a few years, this variety came to dominate the spring wheat area in Finland, and in 1973 occupied 52 per cent of the total spring wheat area (Anon. 1975). The most important characteristics of Ruso are its very stiff straw and good yielding ability, especially in view of the early maturity of the variety. Because of its earliness, Ruso can be grown throughout the Finnish spring wheat production region (KIVI 1970).

In order that this valuable new genotype could be utilized effectively in further breeding work, Ruso was subjected to ${ }^{60} \mathrm{Co}$ mutagen treatment a year before its release. Since the main weakness of Ruso is its susceptibility to sprouting, the mutation breeding programme was directed at improving this character. It was also hoped that any mutants resistant to sprouting would retain the earliness of the mother variety. Our generally wet harvesting seasons have often led to large losses in the quality of wheat crops through sprouting before the crop is combined. The risk is highest with the late ripening varieties.

This paper deals with the main procedures of the breeding programme and with its product, the resulting material. 


\section{Mutagen treatment and selection procedures}

Evenly sized, dry seeds of Ruso spring wheat were irradiated with 15 resp. $20 \mathrm{Krad}$ from the ${ }^{60} \mathrm{Co}$ source of the Institute of Radiochemistry, University of Helsinki. Each seed lot contained approximately 2500 grains.

The amount of material and its treatment in different generations after mutagen treatment (from $\mathrm{M}_{0}$ to $\mathrm{M}_{10}$ ) are described in Table 1 .

Field trials and selection work were carried out at Tammisto and Anttila Experimental Farms in South Finland. The usual procedures worked out for mutation breeding were used. The large scale sprouting resistance screening performed in the $\mathrm{M}_{3}$ was described earlier (KIVI and Ramm-Schmidt 1969). In conjunction with the sprouting resistance investigations on later generations, the falling number test was used. For these tests, a moist chamber was built to incorporate a section with a fairly constant temperature $\left(+11-+14^{\circ} \mathrm{C}\right)$. The higher humidity was maintained with a commercial air-moistener, and the ear samples were placed on the rotating shelves.

Extensive screening of the mutants was carried out also in the $\mathrm{M}_{5}$ (KURRI 1973). The protein analyses were made by the KJELDAHL method.

As well as the mother variety Ruso, Tähti spring wheat was used as a standard of comparison for the mutant lines. This variety, very resistant to sprouting but late maturing, was released by the Plant Breeding Institute of the Finnish Agric. Res. Centre in 1972 (Manner 1972).

Table 1. The procedures of the breeding programme from ${ }^{60} \mathrm{Co}$ treatment the the $\mathrm{M}_{10}$ generation.

\begin{tabular}{|c|c|c|c|}
\hline Year & Generation & Material & Treatment/evaluation \\
\hline 1966 & $\mathrm{M}_{0}$ & $\begin{array}{l}2 \mathrm{x} \text { approx. } 2500 \\
\text { seeds }\end{array}$ & $\begin{array}{l}{ }^{60} \mathrm{Co} \text { treatment, } \\
15 \text { and } 20 \mathrm{Krad}\end{array}$ \\
\hline 1966 & $\mathrm{M}_{1}$ & 517 harvested plants & \\
\hline 1967 & $\mathrm{M}_{2}$ & approx. 7000 plants & $\begin{array}{l}\text { growth rhythm test, } \\
\text { selections for macromutants }\end{array}$ \\
\hline 1968 & $\mathrm{M}_{3}$ & 5700 lines & $\begin{array}{l}\text { sprouting res. screening, new } \\
\text { single plant selections }\end{array}$ \\
\hline 1969 & $\mathrm{M}_{4}$ & 425 lines & $\begin{array}{l}\text { sel. for agronomic characters, } \\
\text { falling number tests }{ }^{1} \text { ) }\end{array}$ \\
\hline 1970 & $\mathrm{M}_{5}$ & 216 lines & $\begin{array}{l}\text { screening for e.g. yield/ } \\
\text { protein relationships }\end{array}$ \\
\hline 1971 & $\mathrm{M}_{6}$ & 76 lines & first actual yield test \\
\hline 1972 & $\mathrm{M}_{7}$ & 23 lines & $\begin{array}{l}\text { comparative trials at } \\
\text { different sites, yield, }\end{array}$ \\
\hline 1973 & $\mathrm{M}_{8}$ & 15 lines & $\begin{array}{l}\text { agronomic characters, grain } \\
\text { quality, baking properties }\end{array}$ \\
\hline 1974 & $\mathrm{M}_{9}$ & 12 lines & first lines for official evaluation \\
\hline 1975 & $\mathrm{M}_{10}$ & 6 lines & \\
\hline
\end{tabular}

1) After $\mathrm{M}_{4}$, falling number tests were included in all generations. 


\section{Variability in the $M_{2}-M_{5}$ generations}

Of the seed material treated, about 10 per cent yielded viable $\mathrm{M}_{1}$ plants capable of setting seed. This survival rate is in accordance with the recommendations for dose - efficiency relationships.

In the $\mathrm{M}_{2}$ and $\mathrm{M}_{3}$ generations, numerous and sometimes very drastic mutants occurred for all conceivable characters e.g. morphological ear characters. This kind of variability has been thoroughly investigated e.g. by MACKEY (1954) and TAVČAR (1964). The number of chlorophyll deviations in the $\mathrm{M}_{2}$ and $\mathrm{M}_{3}$ was extremely low, which is typical of polyploid crop species.

In the $\mathrm{M}_{2}$ generation, the growth rhythm of approximately 4000 individual plants was observed (Fig. 1). This generation is characterized by a significant trend towards late ripening, a phenomenon especially noticeable when the mother genotype is early.

The single plant and pedigree selections made and the testing of selected lines in successive generations in the field and in the moist chamber, led to an altered earliness distribution by the $\mathrm{M}_{5}$ generation (Fig. 1). The general tendency

Fig. 1. Distribution of earliness in different $\mathrm{M}$ generations. Figures have been drawn in which the date of maturity of Ruso has been placed along the same linear regression. In delimiting the searliness classes? in the $\mathrm{M}_{2}$, the time scale was started at a point corresponding to the time of maturity of the earliest lines (class 1). In all generations, two days class intervals are used.

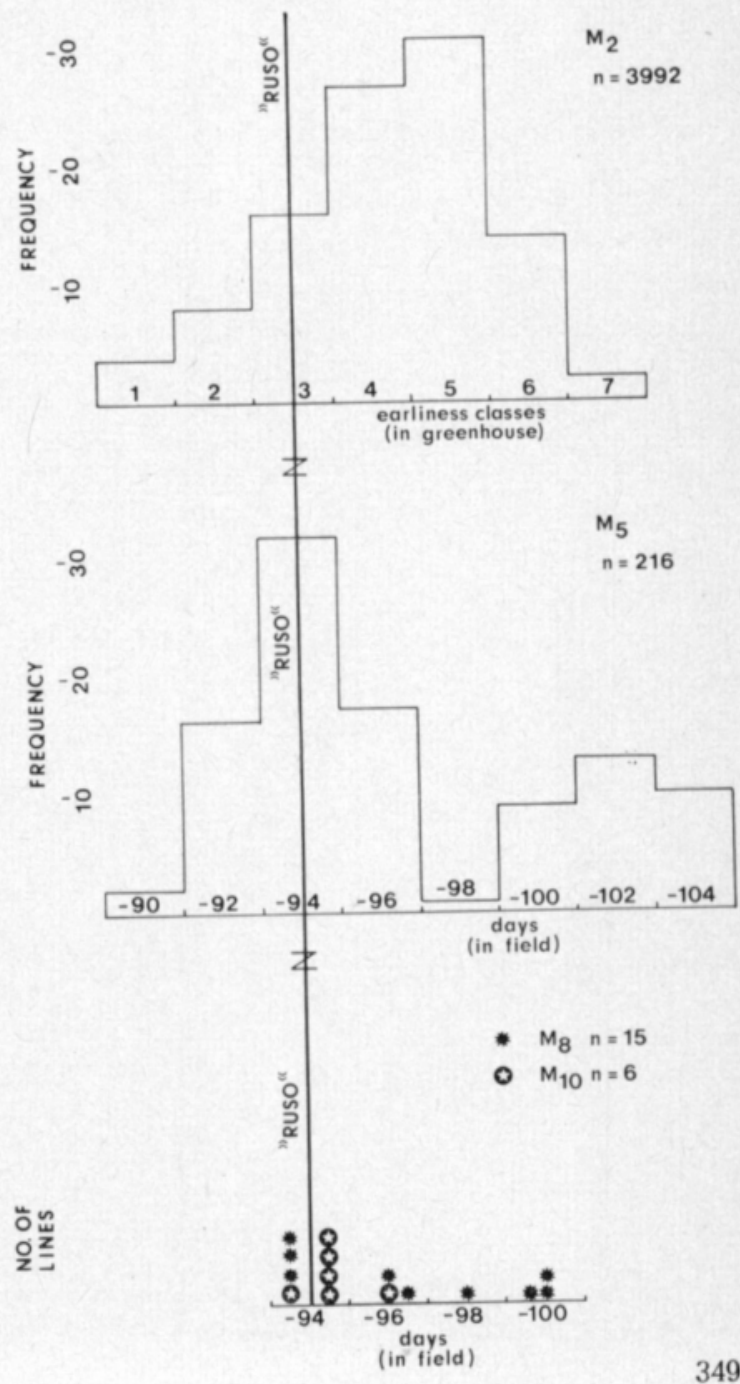


for the level of earliness of the mother variety to persist shifted the major part of the distribution towards the earlier classes. The late-peak in the twopeak distribution curve of the $\mathrm{M}_{5}$ is a result of visual selection for high yielding lines and also of screening for resistance to sprouting in $\mathrm{M}_{3}$. In the $\mathrm{M}_{3}$ generation it was not possible to take into account the degree of maturity of lines comprising the samples for the sprouting chamber. The test, therefore, favoured the late maturing part of the material. In the moist chamber treatments preceding the falling number tests in later generations, this failure was corrected.

The variability of raw protein content was significantly winder among the $216 \mathrm{M}_{5}$ lines investigated than in the 79 samples of the mother cultivar ( $\mathrm{t}$ value $=3.56 * * *, \mathrm{~F}=2.67 * * *)$. The correlation coefficient between protein content and yield in the mutant lines was $\mathrm{r}=-0.82$, while the corresponding figure for Ruso was only $r=-0.20$ (KURRI 1973).

The average yield of the $\mathrm{M}_{5}$ lines was only 82 per cent of the yield of the mother variety. This trend is usual when a high yielding genotype is subjected to mutagen treatment (cf GAUL 1964, KIVI 1965).

\section{The basis for the selection of mutants}

After intensive screening of the $\mathrm{M}_{5}$, the number of lines was decreased to 76 in the $\mathrm{M}_{6}$ (1971), this figure representing a good one per cent of the lines selected or taken in the $\mathrm{M}_{2}$ and $\mathrm{M}_{3}$ generations. These mutants were selected on four different bases: resistance to sprouting (falling number), high protein content, the appearance of a high yield potential and morphological deviation (Table 2). Nearly half of the mutants in the $\mathrm{M}_{6}$ belonged to the last group.

The six "protein mutants" in the $\mathrm{M}_{6}$ were all discarded by the $\mathrm{M}_{8}$. Their poor agronomic characters became apparent as soon as the material was put into yield trials.

Among the lines still present in the trials in the $\mathrm{M}_{10}$ (1975), the basic aim of the breeding program could be resolved: four of the six early maturing mutant lines had been originally selected as sprouting resistant mutants.

Table 2. The distribution of mutant lines in advanced M generations as affected by the basis for selection in $\mathrm{M}_{2}$ or $\mathrm{M}_{3}$.

\begin{tabular}{|c|c|c|c|c|}
\hline Base of selection & Symbol $\left.^{1}\right)$ & $\begin{array}{c}\text { Mutant } \\
\text { M }_{6} \\
(1971)\end{array}$ & $\begin{array}{c}\text { in gene } \\
\mathrm{M}_{8} \\
(1973)\end{array}$ & $\begin{array}{c}\text { (year) } \\
\mathrm{M}_{10} \\
(1975)\end{array}$ \\
\hline Morphological deviation .................... & $\mathrm{m}$ & 31 & 4 & 1 \\
\hline 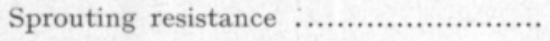 & fn & 22 & 6 & 4 \\
\hline Appearance of high yield............... & y & 17 & 5 & 1 \\
\hline \multirow[t]{2}{*}{ 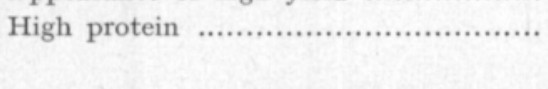 } & $\mathrm{pr}$ & 6 & $\overline{-}$ & $=$ \\
\hline & & $\overline{76}$ & $\overline{15}$ & $\overline{6}$ \\
\hline
\end{tabular}

1) The appropriate symbol is used as a subscript to the mutant line number, and shows the basis upon which each line was selected. 


\section{Sprouting resistance mutants}

The falling number made on the mutants treated in the moist chamber showed that several positive mutations had occurred and mutants were selected in the $\mathrm{M}_{3}-\mathrm{M}_{5}$ generations (Fig. 2). The best mutants seemed to exceed in their resistance even the late ripening variety Tähti (Table 3). Nevertheless, in accordance with the initial idea of the breeding programme, most of the attention was focused on the mutants with a similar growing time to that of Ruso wheat.

Fig. 2. Three sprouting resistant mutant lines (below) selected in the moist chamber in $\mathbf{M}_{\mathbf{3}}$ generation. Above them three badly sprouted samples of the mother variety Ruso.

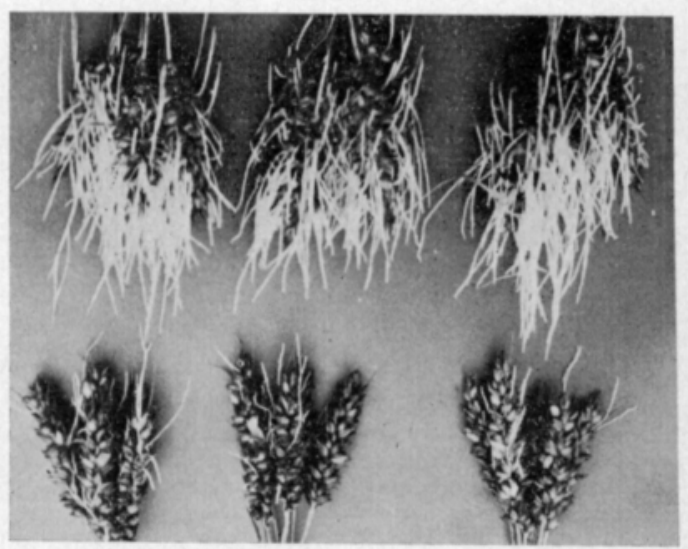

Table 3. The three most sprouting resistant mutants compared with the mother variety Ruso and the late maturing Tähti.

\begin{tabular}{|c|c|c|c|c|c|}
\hline \multirow{2}{*}{$\begin{array}{l}\text { Mutant, } \\
\text { Variety }\end{array}$} & \multicolumn{2}{|c|}{$\begin{array}{l}\text { Falling number } \\
\text { in five tests }\end{array}$} & \multirow{2}{*}{$\begin{array}{c}\text { Growing } \\
\text { time } \\
\text { d }\end{array}$} & \multirow{2}{*}{$\begin{array}{l}\text { Straw- } \\
\text { stiffness } \\
0-100\end{array}$} & \multirow{2}{*}{$\begin{array}{c}\text { Yield } \\
(\text { Ruso }=100)\end{array}$} \\
\hline & aver. & lowest & & & \\
\hline $642 y$ & 237 & 132 & 98 & 50 & 103 \\
\hline $684_{\mathrm{m}}$ & 210 & 124 & 100 & 38 & 103 \\
\hline $523_{\mathrm{fn}}$ & 177 & 114 & 96 & 40 & 90 \\
\hline Tähti & 198 & 109 & 100 & 64 & 103 \\
\hline Ruso & 104 & 60 & 95 & 50 & $3780 \mathrm{~kg} / \mathrm{ha}$ \\
\hline
\end{tabular}

The six mutant lines of the $\mathrm{M}_{10}$ generation had been tested in 12 falling number tests from $1972-74$ (cf. Fig. 3). In six tests, the falling number of Ruso was low (under 125), indicating that its starch was already strongly damaged. In those six tests, the mutant lines, with the exception of line $713_{\text {fn }}$, showed some tendency towards better sprouting resistance (Table 4). Not one of these mutants reached, however, the level of the very resistant Tähti wheat.

The statistical analysis of the material shows that only the mutant $734_{\mathrm{m}}$ was significantly more resistant to sprouting than Ruso (Table 5). Neither this mutant line nor also line $\mathbf{5 5 2}_{\text {fn }}$ were significantly weaker than Tähti. In the half of the test results which included samples whose starch was undamaged or only slightly damaged, no statistically significant differences occurred. 
On the basis of the falling number tests, the mutant lines $734_{\mathrm{m}}$ and $\mathbf{5 5 2}$ in appear to be the most promising types (Fig. 3). Lines $569_{\mathrm{y}}$ and $713_{\mathrm{fn}}$ have been dropped from further investigations, the former because of a weakness in its baking characteristics and the latter on account of a peculiar yearly variability in sprouting resistance.

Thus, the final results of this 10 year breeding programme are, in fact, four reliable mutant lines. Regarding their sprouting resistance they can be put in descending order as follows: $734_{\mathrm{m}}, 552_{\mathrm{fn}}, 689_{\mathrm{fn}}$, and $426_{\mathrm{fn}}$. They are all at least as high yielding as the mother variety (Table 6), but not one of the seems to be a significantly high yielding mutant. Except for the line $734_{m}$, the mutants have stiffer straw than does Ruso. On this basis alone, the lines $689_{\text {fn }}$ and $552_{\text {fn }}$ at least appear to be a worthwhile outcome of the breeding effort. The four mutant lines are at least as early maturing as Ruso. All the investigations of baking quality show that the mutants do not differ significantly from the mother variety.

Table 4. The falling numbers for six mutant lines, the mother variety Ruso, and the variety Tähti in 12 sprouting tests from $1972-75$.

\begin{tabular}{|c|c|c|c|}
\hline & $\begin{array}{c}\text { Average for } 12 \\
\text { test results }\end{array}$ & $\begin{array}{l}\text { Average of the } \\
\text { six best results } \\
\text { (nd) }\end{array}$ & $\begin{array}{l}\text { Average of the } \\
\text { six poorest results } \\
\text { (bd) }\end{array}$ \\
\hline Ruso & 213 & 347 & 80 \\
\hline $426_{\text {fn }}$ & 231 & 353 & 109 \\
\hline 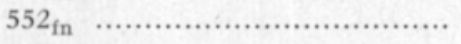 & 222 & 321 & 122 \\
\hline 569 y & 197 & 300 & 94 \\
\hline 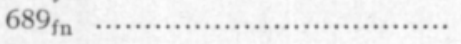 & 216 & 322 & 110 \\
\hline 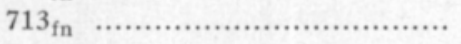 & 188 & 293 & 83 \\
\hline 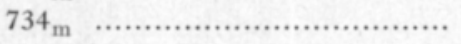 & 233 & 323 & 143 \\
\hline 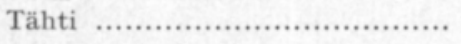 & 259 & 342 & 176 \\
\hline 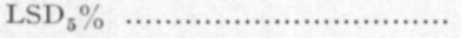 & & 94 & 58 \\
\hline 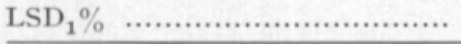 & & 126 & 78 \\
\hline
\end{tabular}

Best and poorest groups formed on the basis of Ruso's falling number.

Table 5. The t-test analysis for the badly damaged group (bd) of falling number tests represented in Table 4.

\begin{tabular}{|c|c|c|c|c|c|c|c|c|}
\hline & Ruso & Tähti & $426_{\mathrm{fn}}$ & $552_{\text {fn }}$ & $569_{y}$ & $689_{\mathrm{fn}}$ & $713_{\mathrm{fn}}$ & $734_{\mathrm{m}}$ \\
\hline Ruso & - & $96.50^{* *}$ & ns & ns & ns & ns & ns & $63.0^{*}$ \\
\hline Tähti & & & $67.33^{*}$ & ns & $82.50^{* *}$ & $66.33^{*}$ & $93.17^{* *}$ & ns \\
\hline $426_{f n}$ & & & & ns & ns & ns & ns & ns \\
\hline $552_{\text {fn }}$ & & & & & ns & ns & ns & ns \\
\hline $569_{y}$ & & & & & & ns & ns & ns \\
\hline $689_{\mathrm{fn}}$ & & & & & & & ns & ns \\
\hline $713_{\mathrm{fn}}$ & & & & & & & & $59.67^{*}$ \\
\hline $734_{m}$ & & & & & & & & - \\
\hline
\end{tabular}

LSD $_{5} \% \quad 57.96^{*}$

$\mathrm{LSD}_{1} \% \quad 77.55^{* *}$ 

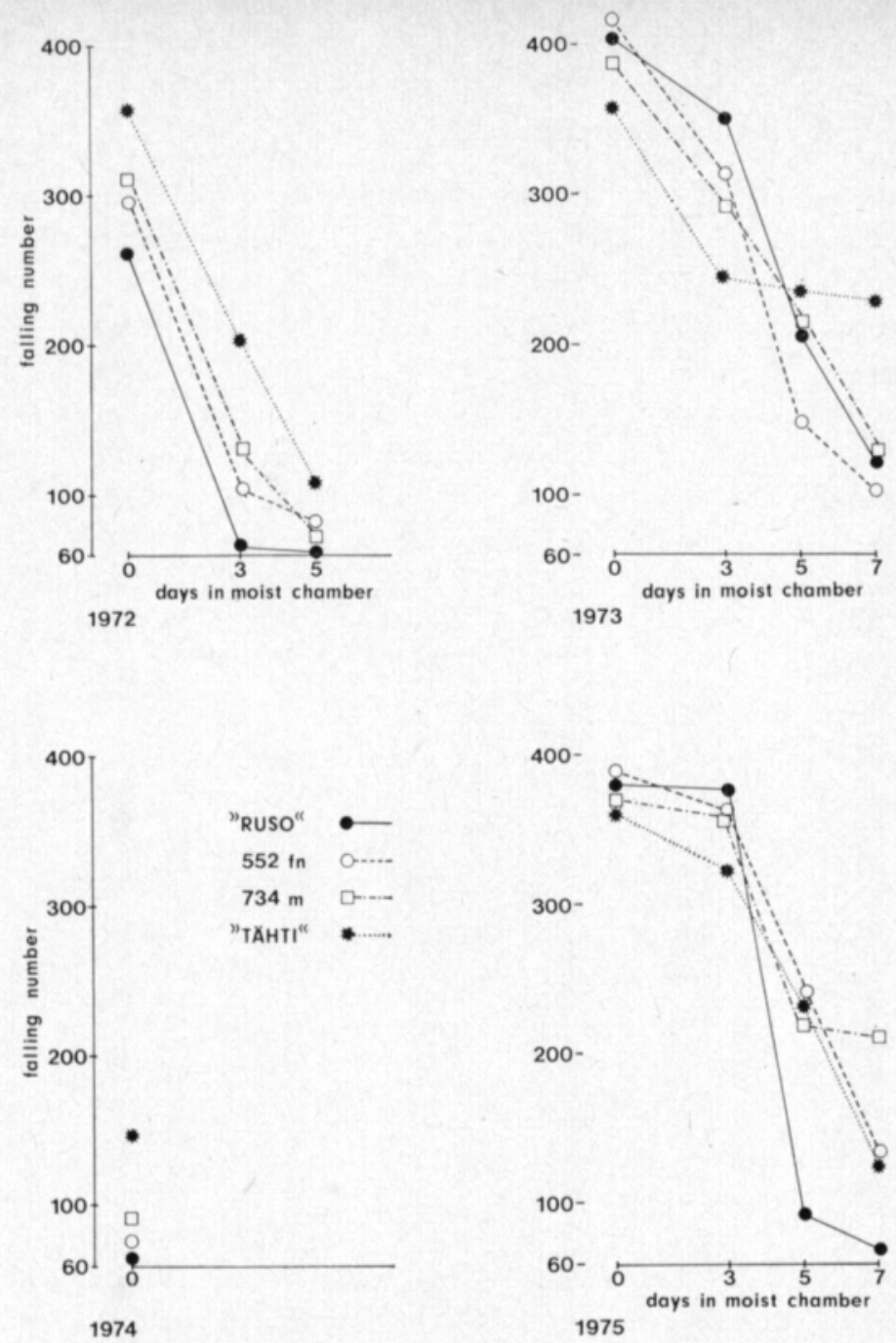

Fig. 3. Falling numbers of the two mutant lines $552_{\mathrm{fn}}$ and $734_{\mathrm{m}}$ in twelve tests from $1972-75$, compared with the mother variety Ruso and with Tähti wheat. Those 12 tests form the basis for the data given in Tables 4 and 5. In 1974, no sprouting tests were made in the moist chamber because wet conditions in the field had already caused widespread sprouting.

Table 6. Characteristics of the wusable mutant liness compared with those of the mother variety Ruso and the late maturing, sprouting resistant Tähti. Results are from the trials in the breeders' trial grounds.

\begin{tabular}{|c|c|c|c|c|c|c|c|c|}
\hline \multirow{2}{*}{$\begin{array}{l}\text { Mutant } \\
\text { line/ } \\
\text { variety }\end{array}$} & \multirow{2}{*}{$\begin{array}{l}\text { No } \\
\text { of } \\
\text { trials }\end{array}$} & \multirow{2}{*}{$\begin{array}{c}\text { Relative } \\
\text { grain yield } \\
(\text { Ruso }=100)\end{array}$} & \multirow{2}{*}{$\begin{array}{l}1000 \\
\text { g.wt } \\
g\end{array}$} & \multirow{2}{*}{$\begin{array}{r}\text { Zeleny } \\
\text { value }\end{array}$} & \multirow{2}{*}{$\begin{array}{c}\text { Test } \\
\text { value } \\
\text { (Pelshenke) }\end{array}$} & \multirow{2}{*}{$\begin{array}{c}\text { Earliness } \\
+ \text { earlier } \\
\text { - later } \\
\text { d }\end{array}$} & \multicolumn{2}{|c|}{ Straw } \\
\hline & & & & & & & $\begin{array}{l}\text { Length } \\
\mathrm{cm}\end{array}$ & $\begin{array}{r}\text { Stiffness } \\
0-100\end{array}$ \\
\hline Ruso & 20 & $3780 \mathrm{~kg}$ & 40.9 & 48 & 138 & 102 & 89 & 80 \\
\hline $426_{\mathrm{fn}}$ & 9 & 103 & -0.6 & -2 & -5 & \pm 0 & -4 & +5 \\
\hline $552_{\mathrm{fn}}$ & 8 & 102 & \pm 0.0 & +2 & -8 & +1 & -8 & +9 \\
\hline $689_{\text {fn }}$ & 14 & 102 & -0.3 & +6 & -5 & \pm 0 & -5 & +10 \\
\hline $734_{m}$ & 11 & 102 & +0.8 & -4 & -10 & \pm 0 & -2 & -4 \\
\hline Tähti & 20 & 106 & -3.4 & +7 & -9 & -5 & +3 & +4 \\
\hline
\end{tabular}




\section{Discussion of the breeding programme}

In this mutation breeding programme, an especially valuable genotype was chosen as the subject of the mutagen treatment. At the time of its release, Ruso was a variety advanced with respect to straw stiffness, yielding ability and earliness.

The mutation breeding programme was begun as soon as we were convinced of the value of the Ruso genotype, in this case one year before its release. Selection after the mutagen treatment was based, primarily on morphologically deviating macromutants and secondarily on randomly chosen samples of individual plants whose pedigrees were tested in the moist chamber for sprouting resistance (physiological mutants, micromutants) (cf. GaUL 1964).

It is quite evident that the ${ }^{60} \mathrm{Co}$ treatment induced sprouting resistant mutations, since such mutants could be isolated. Some of them exceed significantly the level of the mother variety and even that of the cultivar Tähti, most resistant to sprouting. In Norway, Frogner ((1969) has obtained positive results in his mutation breeding programme for sprouting resistance in wheat.

In an earlier study, it was also shown that more than one sprouting resistant mutant frequently originates from a single ear of the $\mathrm{M}_{1}$ plant, behaviour typical of a mutagen like ${ }^{60} \mathrm{Co}$ (KIvi and RAmm-Schmidt 1969).

During the execution of a breeding programme also the practical aspect of changes in the variety situation must be considered. The handling of the latest generations of this programme was largely influenced by the release of the late maturing, very sprouting resistant wheat Tähti in 1972. This variety ripens five days later than Ruso. Its release reduced the practical value of a large group of the most sprouting resistant but late ripening mutant lines. This can be seen also in the distribution of earliness (cf. Fig. 1). While in the $\mathrm{M}_{8}$ (1973) there were still mutants with a growing time several days longer than that of Ruso, nevertheless by the $M_{10}$ (1975), all the late lines had disappeared and the growing times of the remaining mutants were clustered around that of the mother variety.

The lack of truly high yielding mutants in this material is not surprising, since Ruso itself was at the time of its release a remarkable advance in yielding ability, quite apart from its earliness. Breakage of the negative correlation between the protein content and yield potential seems to be extremely difficult in highly bred wheat crop (DENIĆ et al. 1976).

A most surprising result of the study is the isolation of stiffness mutants, since as regards resistance to lodging Ruso itself was a great step forward.

In any highly bred crop species, as is hexaploid bread wheat, the progress which mutant cultivars or elites can confer directly upon production is normally rather small - although not without significance, as is evidenced by the final results of this breeding programme. The more drastic mutants include normally harmful pleiotropic and/or linkage relationships; the elimination of those warrants further breeding efforts.

Acknowledgements. The ${ }^{60} \mathrm{Co}$ treatments of material were performed by Mr. T. Autio, M.Sc., at the Institute of Radiochemistry, University of Helsinki; Dr. H. Walther, Abteilung Pflanzengenetik, Grünbach, GFR, gave statistical advise, and Mr. P. Joy, M.Sc. Agr., revised the English text; Miss Lea Jaakkola from the authors' Institute carried out the main part of moist chamber tests. We acknowledge these cooperating colleagues and research units. 


\title{
REFERENCES
}

ANoN. 1975. Kylvösiemenotanta 1973. Res. Reports, Reports, Res. Lab. of Grain Res. Comm. and State Granary 2/75: 1-59.

Denić, M., Dumanović, J., Konstantinov, K. \& Simić, R. 1976. Some characteristics of induced variation in protein quantity and quality in wheat. Genetika (Yugoslavia) 1976, (in press).

Frogner, S. 1969. Avkastning og kvalitet hos vårhvete. State Exp. Sta. Møystad, Rep. No 63: $67-94$.

Gaul, H. 1964. Induced mutations in plant breeding. Genetics Today, Pergamon Press. p. $689-709$.

Krvi, E. I. 1965. The environmental influence on the incidence and selection of mutations. Proc. Symp. on the Mutational Process, Prague, p. 153-158.

— - 1970. Ruso ja Veka - uudet kevätvehnälajikkeet. Hankk. Siemenjulk. p. 151-157.

- - \& Ramm-Schміdт, C. 1969. Selection for resistance to sprouting in ${ }^{60} \mathrm{Co}$-irradiated wheat. Induced Mutations in Plants, IAEA Vienna. p. 535-540.

KURRI, P. 1973. ${ }^{60}$ Co-säteilytetyn kevätvehnän $\mathrm{X}_{5}$ - ja $\mathrm{X}_{6}$-populaatioiden muuntelusta. Thesis for M.Sc. Agr., Institute of Plant Breeding Res., Univ. Helsinki. p. 1-27 (stenciled copy).

MAскEY, J. 1954. Neutron and X-ray experiments in wheat and a revision of the speltoid problem. Hereditas 40: 65-180.

Manner, R. 1972. Tähti-kevätvehnä. Koetoim. ja Käytäntö 29, 6:22-23.

TAV̌̌Ar, A. 1964. Gamma-ray irradiation of seeds of wheat, barley and inbreds of maize, and the formation of some useful point mutations. The Use of Ind. Mutations in Plant Breeding, Pergamon Press. p. 159-174.

Ms received September 13, 1976.

\section{SELOSTUS}

\section{Tähkäidännänkestävyys vehnän mutaatiojalostusohjelman tavoitteena}

\author{
E. I. Krvi ja S. Hovinen \\ Hankkijan kasvinjalostuslaitos, 04300 Hyrylä
}

Ruso-kevätvehnän tähkäidännänkestävyyden parantamiseksi suoritettiin sen mutagenssikäsittely radiokoboltilla $\left({ }^{60} \mathrm{Co}\right)$ vuonna 1966 . Käyttäen ns. kostean kammion menetelmää ja sakoluvunmääritystä löydettiin useita tähkäidännänkestäviä mutaatiolinjoja, joista parhaimmat kuitenkin ovat selvästi Rusoa myöhäisempiä.

Käytännōn jalostustavoitteeksi oli asetettu Ruson aikaisuutta olevien tähkäidännänkestävien mutanttien tavoittaminen. Aineiston $\mathrm{M}_{10}$-polvessa (1975) oli jäljellä neljä käyttōkelpoista linjaa, jotka aikaisuudeltaan ja satoisuudeltaan ovat Ruson veroisia ja sakoluvultaan sitä varmempia. Kaksi näistä linjoista on selvästi Rusoa lujakortisempia. 